\title{
Vacunación con vacuna triple bacteriana acelular a todos los adolescentes de once años de edad y al personal de salud en Argentina
}

Resumen de la publicación del Boletín Oficial del 28-abr-2009 del Ministerio de Salud.

\begin{abstract}
Resumen
A través de la resolución 506/2009 del Ministerio de Salud se ha incorporado al Programa Ampliado de Inmunizaciones con carácter gratuito y obligatorio, la inmunización con la vacuna triple bacteriana acelular a todos los adolescentes de once años de edad y al personal de salud, incluyéndola en el Calendario Nacional de Inmunizaciones.
\end{abstract}

Actualmente la República Argentina posee en su calendario regular de vacunación cinco dosis del componente pertussis celular incorporado en las vacunas combinadas de tres, cuatro y cinco componentes, que se administran a los dos, cuatro, seis, 18 meses y seis años de edad.

Sin embargo, la incidencia de la enfermedad por Bordetella pertussis ha aumentado en la mayoría de las jurisdicciones de Argentina, presentando un mayor impacto en los menores de seis meses en quienes se registra la mayor morbilidad y mortalidad. Por otro lado, la fuente de contagio de los menores de seis meses es el contacto con adultos jóvenes (hermanos, madre, padre, cuidadores).

Si bien las vacunas celulares disponibles en la actualidad en el Calendario Nacional de Inmunizaciones no están recomendadas en este grupo de edades, actualmente se encuentran disponibles vacunas combinadas acelulares que contienen el componente pertussis y pueden aplicarse a adolescentes y adultos -existen dos laboratorios productores de vacuna triple bacteriana acelular aprobadas por la Administración Nacional de Medicamentos Alimentos y Tecnología (ANMAT).

A fin de disminuir la incidencia de esta enfermedad se convocó a la Comisión Nacional de Inmunizaciones, generándose las siguientes recomendaciones:

1. Realizar un adecuado control de foco, administrando quimioprofilaxis y completando los esquemas de vacunación cuando estén indicados, para disminuir la circulación de la Bordetella y el contagio a los lactantes pequeños.

2. Asegurar las cinco dosis en los menores de seis años, llegando al indicador de $95 \%$ de cobertura con las vacunas del programa regular.

3. Incorporar la vacuna triple bacteriana acelular (difteria, tétanos y pertussis acelular) a los once años de edad y al personal de salud en el Calendario Nacional de Inmunizaciones para el año 2009. El motivo de esta recomendación es que al disminuir la circulación de la Bordetella Pertussis no hay refuerzo natural de la enfermedad y se correla aparición clínica de esta enfermedad a edades mayores.

Vietto V y Terrasa S. Vacunación con vacuna triple bacteriana acelular a todos los adolescentes de once años de edad y al personal de salud en Argentina. Evid. Act. Pract. Ambul. 12(2).49. Abr-Jun. 2009. Resumido de: http://www.saij.jus.gov.ar/news/files/resolucion506.html

\section{CARTA DE LECTORES}

En relación al artículo: Terceiro D y Barán P. Un caso de criptorquidia. Evid. Act. Pract. Ambul. 12(1). 22-23 Ene-Mar 2009. Disponible en URL: http://www.foroaps.org/files/criptorqui.pdf

De acuerdo a lo publicado en dicho artículo y en relación a la descripción que hacen los autores sobre la estimulación con gonadotrofina coriónica humana (hCG) -nombrándola en primer lugar- considero que puede generarse confusión sobre el manejo actual de la criptorquidia. Por ejemplo, puede darse a entender que en la actualidad se sigue utilizando como primera elección dicha estimulación con hCG.

Tanto el último Consenso Nórdico sobre testículos no descendidos, como el Comité Nacional de Endocrinología de la Sociedad Argentina de Pediatría ( 2009) consensuaron no utilizar hCG como primera línea de tratamiento considerando sus pobres resultados inmediatos y sus posibles efectos adversos a largo plazo sobre la espermatogénesis, reservando su indicación solo en algunos casos seleccionados. Por lo tanto, la cirugía es el tratamiento de preferencia, recomendándose una derivación precoz de los pacientes con criptorquidia al especialista, quien probablemente los reevaluará entre los seis meses y el año de vida. De no haber descendido espontáneamente los testículos al año de vida se sugiere realizar la cirugía, a cargo de un cirujano ó urólogo pediátrico (descenso escrotal de los testículos); recomendándose la realización de la misma antes de los dos años de vida (algunos trabajos la recomiendan a partir de los nueve meses de vida). Por ahora no está recomendada la estimulación con hCG previa a la cirugía con la finalidad de facilitar el acto quirúrgico.

\footnotetext{
Javier Chiarpenello [ Médico Endocrinólogo, Unidad de Endocrinología Infantil del Hospital Centenario de Rosario. Servicio de Endocrinología del Hospital Centenario de Rosario. jchiarpenello@ hotmail.com ]
}

\section{Referencia}

1. E. Martín Ritzen y col. Nordic consensos on treatment of undescended testes. Review article. Acta Pediatrica 2007; 96:638-43.

2. Gryngarten M y col. Tendencias actuales en el tratamiento y seguimiento de la criptorquidia. Arch Argent Pediatr 2009; 107(2):176-180. 